\title{
Korea-ASEAN Trade Flows and the Role of AFTA: Sector-Specific Evidence of Trade Diversion*
}

\author{
Yoon $\mathrm{Heo}^{* *}$ \\ Tran N. Kien***
}

\begin{abstract}
This article examines the impact of the ASEAN Free Trade Area (AFTA) on Korean exports to ASEAN countries by using the system generalized method of moments. The data covered 15 sectors according to their relative importance in Korean exports and spanned from 1980 to 2006. The estimated results suggest that Korea's exports were diverted to ASEAN members as a result of the AFTA formation. In 5 of the 15 sectors, the AFTA exerted a significant negative effect on Korean exports to ASEAN countries, but for the remaining 9, the results were mixed and statistically insignificant. The results also indicate that the sectoral approach yields more robust and clear-cut results than the aggregate one.
\end{abstract}

Keywords: Trade Diversion, Gravity Model, SYS-GMM, Korea, AFTA

JEL Classification Numbers: F13, F14, F15

Submission Date: 03/16/2012

Revision Date: 08/10/2012

Acceptance Date: 08/14/2012

* This research was supported by a Special Research Grant from Sogang University (2011-10075.01) and a Research Grant for Asian Studies from the POSCO TJ Park Foundation . The authors are grateful for the financial support from Sogang University and POSCO. An earlier version of this paper was presented at the SOGANG II AS RESEARCH SERIES ON INTERNATIONAL AFFAIRS and at the POSCO Asian Forum.

** Yoon Heo, Professor of International Trade, Graduate School of International Studies, Sogang University, Seoul, 121-742, Korea. Tel:82-2-705-8948, Fax: 82-2-705-8755, E-mail: hury@sogang.ac.kr

*** Tran N. Kien, Vice-Dean, Faculty of Post-Graduate Studies, Thainguyen University of Economics and Business Administration, Street 3/2, Tich Luong Ward, Thainguyen Province, Vietnam. Tel:84-280-647752, Fax: 84-280-647684, E-mail: khiueong@yahoo.com 


\section{INTRODUCTION}

In the past two decades, regional trade agreements (RTAs) have spread, grown, and deepened. Even after the establishment of the World Trade Organization (WTO) in 1995, a large number of new RTAs have been formed, challenging both economists and policy markers. This proliferation of RTAs has resulted in ongoing controversy among experts over whether RTAs are building blocks or stumbling blocks for free trade. Thus far, there has been no consensus on the impact of RTAs on member and non-member countries. Supporters of RTAs have argued that such agreements may help to "lock in" liberalization, yielding domestic regulatory reforms and trade creation. Conversely, critics have asserted that the formation of RTAs undermines support for multilateral liberalization efforts and pulls the political focus away from multilateralism. RTAs are likely to create bloc market power and protection incentives, bringing about a trade diversion effect. It has also been argued that RTAs among developing countries, such as the ASEAN Free Trade Area (AFTA), may have additional adverse effects on trade patterns among member countries and between member and non-member countries. This suggests that the effects of RTAs on trade flows between member and non-member countries should be evaluated only on a case-by-case basis.

The AFTA was implemented in 1993 by ASEAN-6 countries (Brunei, Indonesia, Malaysia, the Philippines, Singapore, and Thailand) and is aimed primarily at integrating member countries into a single production base and creating a regional market of approximately 550 million people. To this end, member countries agreed to lower or eliminate tariffs and non-tariff barriers within 15 years of its implementation. The main instrument of the tariff reduction scheme has been the Common Effective Preferential Tariff (CEPT), which covers both manufactured and agricultural products. However, following the Asian financial crisis in 1997, the member countries decided at the sixth ASEAN summit in December 1998 to accelerate trade liberalization by revising the timetable to 2002. In the mid-1990s, four more countries (CLMV) joined ASEAN: Vietnam (1995), Myanmar, (1998), Laos (1998), and Cambodia (1999). These countries are also participating in the AFTA under the following deadlines: Vietnam in 2006, Myanmar and Laos in 2008, and Cambodia in 2010.

Korea is a major trading partner with ASEAN countries. The ASEAN countries have proven to be important markets for Korea's manufactured products, and Korea has relied heavily on raw materials and light manufactured products which are imported from ASEAN countries. Nevertheless, Korea's exports to ASEAN countries have declined steadily in recent years; while exports, which accounted for $5.2 \%$ of Korea's total exports in 1988, rose to $15.7 \%$ in 1996 and then declined steadily to $9.6 \%$ in 2005 (KITA, 2007). From the Korean perspective, trade diversion is likely because of the preferential treatment that is granted by ASEAN countries to their members. As discussed in Section II, the intensity of bilateral trade between Korea and 
ASEAN has decreased, and the degree of the regional trade orientation of both Korea and ASEAN to their respective market has weakened in recent years. Therefore, it is important to determine the extent to which trade diversion from the AFTA has affected Korean exports to AFTA members. This paper is guided by the following research questions:

* First, what are the effects of the AFTA on Korean exports to ASEAN countries?

* Second, what are its effects on Korean exports in different industries?

* Third, what are the key determinants of Korean exports to ASEAN countries?

* Fourth, what are the characteristics of trade patterns between Korea and ASEAN countries?

This study contributes to the literature in several ways. First, this study estimates the effects of the AFTA on Korean trade flows by using sectoral data, not aggregate trade data, which allows it to capture sector-specific effects across industries, principally because the removal of trade barriers under the AFTA follows very different timetables depending on products. Indeed, many products are subject to exclusion from the Inclusion List under the CEPT. However, no study has employed sectoral data to assess the impact. Second, this study uses the SYS-GMM (system generalized method of moments), a key tool for estimating such effects because it can address the problems of heteroskedasticity and autocorrelation in panel data and the dynamic characteristics of such data. Third, instead of pooling data across various countries, this study focuses solely on the effects of the AFTA on Korean exports. Finally, this study provides an in-depth understanding of the dynamic patterns in bilateral trade relations between Korea and ASEAN over the past two decades.

The rest of this paper proceeds as follows. Section II addresses the evolution of bilateral trade between Korea and ASEAN. Section III specifies the model, data, and estimation methods. Section IV presents and discusses the results, and Section V concludes.

\section{TRADE RELATIONS BETWEEN KOREA AND ASEAN}

This section analyzes the trade relationship between Korea and ASEAN in order to evaluate changes in trade patterns as a result of the AFTA ${ }^{1)}$. Table 1 presents the trade pattern between Korea and the ASEAN-6 from 1989-2006. The first and second

1) Our analysis focuses on ASEAN-6 countries because of the lack of data at disaggregated levels for CLMV countries. 
parts of the table show the exports and imports of ASEAN-6 with respect to Korea, respectively, as well as their trade at the one-digit SITC for the selected years between 1989 and 2006. Overall, the trade patterns between Korea and ASEAN countries have changed dramatically over the past two decades. Table 1 suggests several important features.

Trade between ASEAN-6 and Korea has expanded considerably in recent years. Bilateral trade between ASEAN-6 and Korea increased more than sevenfold from less than $\$ 8$ billion in 1989 to more than $\$ 56$ billion in 2006. Although trade volume declined between 1997 and 1998, when both parties were battered by the Asian financial crisis, it recovered soon after in 1999. Bilateral trade rebounded to nearly $\$ 25$ billion by the end of 1999 and expanded to over \$33 billion in 2001, rising above the pre-crisis levels.

Table 1.

Bilateral Trade Between ASEAN-6 and Korea, 1989-2006

\begin{tabular}{|c|c|c|c|c|c|c|c|c|c|c|c|c|}
\hline & \multirow{2}{*}{ Year } & \multirow{2}{*}{$\begin{array}{l}\text { Total } \\
\text { trade }\end{array}$} & \multicolumn{10}{|c|}{ Trade by Commodity (percent) } \\
\hline & & & SITC-0 & SITC-1 & SITC-2 & SITC-3 & SITC-4 & SITC-5 & SITC-6 & SITC-7 & SITC-8 & SITC-9 \\
\hline \multirow{10}{*}{$\begin{array}{l}A S E \\
\text { AN- } \\
\text { 6's } \\
\text { Exp } \\
\text { orts }\end{array}$} & 1989 & 3.76 & 6.19 & 0.04 & 19.53 & 36.22 & 2.18 & 3.78 & 13.35 & 15.47 & 2.55 & 0.69 \\
\hline & 1991 & 5.82 & 5.57 & 1.73 & 13.31 & 42.99 & 1.78 & 3.56 & 12.39 & 15.32 & 3.05 & 0.30 \\
\hline & 1993 & 6.83 & 4.66 & 3.86 & 11.47 & 36.55 & 1.66 & 4.91 & 15.19 & 17.12 & 3.81 & 0.78 \\
\hline & 1995 & 9.44 & 4.92 & 2.41 & 12.83 & 24.66 & 1.73 & 7.06 & 14.99 & 25.45 & 4.88 & 1.08 \\
\hline & 1997 & 11.61 & 4.42 & 1.51 & 7.20 & 36.95 & 1.38 & 5.75 & 11.03 & 26.34 & 3.87 & 1.55 \\
\hline & 1999 & 11.30 & 2.58 & 0.95 & 6.18 & 28.27 & 1.21 & 6.02 & 10.22 & 40.48 & 3.48 & 0.62 \\
\hline & 2001 & 14.08 & 2.69 & 0.13 & 5.73 & 28.65 & 0.74 & 5.89 & 8.77 & 42.19 & 4.29 & 0.93 \\
\hline & 2003 & 16.77 & 2.87 & 0.06 & 5.35 & 26.06 & 0.85 & 6.46 & 8.92 & 44.50 & 4.33 & 0.59 \\
\hline & 2005 & 23.62 & 2.30 & 0.16 & 6.18 & 30.68 & 0.74 & 7.05 & 7.26 & 40.65 & 4.14 & 0.84 \\
\hline & 2006 & 27.47 & 2.05 & 0.14 & 7.00 & 33.82 & 0.57 & 7.01 & 8.24 & 36.26 & 4.06 & 0.84 \\
\hline \multirow{10}{*}{$\begin{array}{l}\text { ASE } \\
\text { AN- } \\
\text { 6's } \\
\text { Imp } \\
\text { orts }\end{array}$} & 1989 & 3.81 & 1.64 & 0.24 & 2.07 & 0.37 & 0.01 & 10.10 & 36.57 & 39.22 & 5.95 & 3.85 \\
\hline & 1991 & 6.53 & 2.75 & 0.11 & 1.36 & 8.08 & 0.01 & 9.69 & 35.33 & 36.45 & 5.76 & 0.45 \\
\hline & 1993 & 9.05 & 1.50 & 0.03 & 1.43 & 5.00 & 0.01 & 12.42 & 32.65 & 39.35 & 5.91 & 1.70 \\
\hline & 1995 & 14.73 & 0.95 & 0.02 & 1.28 & 1.68 & 0.02 & 10.85 & 22.77 & 55.79 & 4.41 & 2.23 \\
\hline & 1997 & 14.57 & 0.81 & 0.05 & 1.11 & 3.22 & 0.03 & 10.05 & 22.37 & 57.12 & 4.86 & 0.38 \\
\hline & 1999 & 13.46 & 0.80 & 0.01 & 1.22 & 4.25 & 0.02 & 9.30 & 17.93 & 61.73 & 4.38 & 0.36 \\
\hline & 2001 & 13.29 & 0.89 & 0.12 & 1.42 & 6.45 & 0.03 & 11.41 & 19.06 & 56.19 & 3.86 & 0.56 \\
\hline & 2003 & 16.63 & 0.69 & 0.03 & 0.96 & 3.56 & 0.03 & 9.48 & 14.52 & 66.47 & 3.74 & 0.53 \\
\hline & 2005 & 23.38 & 0.68 & 0.04 & 0.93 & 8.86 & 0.02 & 9.02 & 15.06 & 62.30 & 2.45 & 0.63 \\
\hline & 2006 & 28.74 & 0.66 & 0.04 & 0.76 & 8.83 & 0.03 & 8.77 & 14.74 & 63.40 & 2.32 & 0.45 \\
\hline
\end{tabular}

Note: SITC-0: food and live animals; SITC-1: beverages and tobacco; SITC-2: crude materials and inedible, except fuels; SITC-3: mineral fuels, lubricants, and 
related goods; SITC-4: animal, vegetable oils and fats; SITC-5: chemicals; SITC-6: manufactured goods classified chiefly by materials; SITC-7: machinery and transport equipment; SITC-8: miscellaneous manufactured articles; SITC-9: commodities and transactions not classified elsewhere in the SITC. Total trade is in billions of USD.

Source: COMTRADE database.

With regard to exports, ASEAN-6's exports to Korea increased more than 7.3 times, from $\$ 3.8$ billion in 1989 to $\$ 27.5$ billion in 2006 . On the other hand, its imports from Korea increased more rapidly than its exports over the same period. As a consequence, Korea recorded a constant trade surplus over this entire period (except for 2001-05).

In terms of commodity trade, there were sizeable shifts in the share amount of most product groups during the sample period, but the most notable shift took place in machinery and transport equipment (SITC-7). The share of ASEAN-6's exports to Korea reported an increasing trend in chemicals (5), machinery and transport equipment (7), and miscellaneous manufactured articles (8), whereas that of food and live animals (0), crude materials, inedible except fuels (2), and manufactured goods classified chiefly by material (6) reported a declining trend. In terms of ASEAN's imports from Korea, there was a substantial increase in the amount of machinery and transport equipment (7) between 1989 and 2006. Accordingly, machinery and transport equipment (7) accounted for almost two thirds of ASEAN's imports from Korea in 2006. On the other hand, the share of manufactured goods classified chiefly by materials (6) in ASEAN's imports declined considerably.

Table 2 shows the exports of Korea and ASEAN to their major trading partners worldwide. Korea's exports to China increased sharply after the normalization of diplomatic relations between the two countries in 1992, but this came at the expense of exports to the U.S. and Japan. Korea's exports to ASEAN in percentage, which increased considerably between the late 1980s and the early 1990s, have gradually declined since the mid-1990s. 
Table 2.

Exports of Korea and ASEAN Countries (1985-2006)

\begin{tabular}{|c|c|c|c|c|c|c|c|c|}
\hline \multirow{2}{*}{$\begin{array}{l}\text { Country/ } \\
\text { Year }\end{array}$} & \multirow{2}{*}{$\begin{array}{l}\text { Exports to } \\
\text { the World } \\
(\$ \text { mill. })^{I}\end{array}$} & \multicolumn{7}{|c|}{ Share of Total Exports (percent) } \\
\hline & & $E U$ & Korea & NAFTA & U.S & Japan & China & ASEAN \\
\hline \multicolumn{9}{|l|}{ Korea } \\
\hline 1985-1989 & $46,727.6$ & 13.33 & - & 39.89 & 36.28 & 18.65 & 0.00 & 5.04 \\
\hline $1990-1994$ & $80,941.3$ & 12.21 & - & 26.54 & 23.50 & 15.24 & 3.71 & 10.89 \\
\hline 1995-1999 & $137,955.2$ & 12.48 & - & 19.65 & 17.51 & 10.98 & 8.66 & 13.30 \\
\hline $2000-2004$ & $187,210.6$ & 13.20 & - & 21.86 & 19.18 & 9.73 & 15.52 & 10.61 \\
\hline 2005 & $284,337.0$ & 13.68 & - & 17.14 & 14.60 & 8.45 & 21.78 & 9.65 \\
\hline 2006 & $325,386.0$ & 12.55 & - & 16.36 & 13.31 & 8.15 & 21.35 & 9.85 \\
\hline \multicolumn{9}{|l|}{ ASEAN-6 } \\
\hline $1985-1989$ & $89,563.4$ & 13.10 & 3.00 & 21.81 & 20.87 & 20.99 & 2.12 & 17.85 \\
\hline $1990-1994$ & $191,546.1$ & 14.31 & 3.30 & 20.82 & 19.65 & 16.36 & 2.19 & 21.26 \\
\hline 1995-1999 & $331,977.1$ & 14.62 & 3.26 & 20.55 & 19.52 & 13.21 & 2.93 & 23.11 \\
\hline $2000-2004$ & $428,608.5$ & 13.49 & 3.83 & 18.08 & 16.92 & 12.62 & 5.47 & 23.99 \\
\hline 2005 & $613,053.1$ & 11.92 & 3.95 & 15.00 & 14.10 & 11.10 & 8.01 & 25.67 \\
\hline 2006 & $717,955.4$ & 11.89 & 3.82 & 14.59 & 13.63 & 10.74 & 8.79 & 25.27 \\
\hline \multicolumn{9}{|l|}{ CLMV } \\
\hline $1985-1989$ & $1,453.9$ & 4.28 & 1.85 & 0.31 & 0.22 & 7.68 & 0.97 & 9.84 \\
\hline $1990-1994$ & $3,932.0$ & 8.15 & 2.04 & 1.82 & 1.55 & 22.36 & 5.75 & 23.37 \\
\hline 1995-1999 & $10,873.8$ & 16.77 & 3.37 & 6.30 & 5.49 & 15.65 & 5.47 & 24.03 \\
\hline $2000-2004$ & $23,222.2$ & 18.92 & 2.18 & 18.20 & 16.99 & 12.65 & 8.67 & 17.77 \\
\hline 2005 & $39,863.7$ & 15.68 & 1.80 & 20.57 & 18.87 & 11.53 & 8.82 & 20.30 \\
\hline 2006 & $48,948.2$ & 16.00 & 1.94 & 21.69 & 19.92 & 11.26 & 7.22 & 20.29 \\
\hline \multicolumn{9}{|l|}{ ASEAN } \\
\hline $1985-1989$ & $91,017.3$ & 12.96 & 2.98 & 21.47 & 20.54 & 20.78 & 2.10 & 17.73 \\
\hline $1990-1994$ & $195,478.1$ & 14.19 & 3.28 & 20.43 & 19.29 & 16.48 & 2.26 & 21.30 \\
\hline 1995-1999 & $342,850.9$ & 14.69 & 3.26 & 20.09 & 19.08 & 13.28 & 3.01 & 23.14 \\
\hline $2000-2004$ & $451,830.8$ & 13.77 & 3.75 & 18.09 & 16.93 & 12.62 & 5.64 & 23.67 \\
\hline 2005 & $652,916.8$ & 12.15 & 3.82 & 15.34 & 14.39 & 11.12 & 8.06 & 25.34 \\
\hline 2006 & $766,903.6$ & 12.15 & 3.70 & 15.05 & 14.03 & 10.78 & 8.69 & 24.96 \\
\hline
\end{tabular}

Note: 1): Average for the period.

Source: Direction of Trade Statistics CD-Rom, IMF, 2008. 
The share of ASEAN's exports to the U.S. and Japan also declined. ASEAN's exports to Japan (as a percentage of its total exports) witnessed the largest decline, from over 20\% between 1985 and 1989 to less than 11\% in 2006. ASEAN's exports to the U.S. also decreased sharply. In addition,

Table 3.

Trade Intensity Index for Korea and ASEAN countries (1980-2006)

\begin{tabular}{|c|c|c|c|c|c|c|c|c|c|c|}
\hline $\begin{array}{l}\text { Exporter } \\
\text { (Period) }\end{array}$ & $\begin{array}{l}\text { Indon- } \\
\text { esia }\end{array}$ & $\underset{\text { sia }}{\text { Malay- }}$ & $\begin{array}{l}\text { Philip- } \\
\text { pines }\end{array}$ & $\begin{array}{l}\text { Singa- } \\
\text { pore }\end{array}$ & $\begin{array}{l}\text { Thaila- } \\
\text { nd }\end{array}$ & $\begin{array}{l}\text { Vietna- } \\
m\end{array}$ & Korea & U.S. & Japan & China \\
\hline \multicolumn{11}{|l|}{ Indonesia } \\
\hline 1980-1989 & & 0.76 & 2.52 & 7.20 & 0.83 & 1.60 & 2.07 & 1.22 & 7.62 & 0.55 \\
\hline 1990-1999 & & 1.74 & 1.96 & 4.77 & 1.37 & 3.62 & 3.08 & 0.88 & 4.89 & 1.46 \\
\hline $2000-2004$ & & 3.08 & 2.42 & 5.36 & 2.37 & 2.46 & 3.15 & 0.76 & 4.65 & 1.20 \\
\hline 2005 & & 3.80 & 3.27 & 5.45 & 2.62 & 2.39 & 3.64 & 0.74 & 4.70 & 1.38 \\
\hline 2006 & & 3.80 & 2.85 & 5.22 & 2.76 & 2.97 & 3.25 & 0.75 & 4.91 & 1.39 \\
\hline \multicolumn{11}{|l|}{ Malaysia } \\
\hline 1980-1989 & 1.57 & & 4.31 & 14.05 & 5.06 & 0.44 & 3.50 & 1.00 & 3.35 & 0.94 \\
\hline 1990-1999 & 2.29 & & 2.16 & 9.92 & 3.51 & 2.08 & 1.53 & 1.27 & 2.28 & 0.95 \\
\hline $2000-2004$ & 3.20 & & 2.45 & 9.52 & 4.59 & 2.48 & 1.49 & 1.17 & 2.40 & 1.21 \\
\hline 2005 & 3.06 & & 2.76 & 9.29 & 5.38 & 2.48 & 1.48 & 1.27 & 2.08 & 1.17 \\
\hline 2006 & 3.60 & & 2.77 & 9.07 & 5.45 & 3.11 & 1.54 & 1.26 & 2.02 & 1.21 \\
\hline \multicolumn{11}{|l|}{ Philippines } \\
\hline $1980-1989$ & 1.94 & 3.70 & & 2.28 & 2.29 & 2.18 & 1.87 & 2.26 & 3.41 & 0.83 \\
\hline 1990-1999 & 0.77 & 2.34 & & 2.74 & 2.47 & 3.04 & 1.08 & 2.22 & 2.86 & 0.49 \\
\hline $2000-2004$ & 1.05 & 4.07 & & 4.12 & 3.57 & 2.08 & 1.50 & 1.41 & 3.40 & 0.95 \\
\hline 2005 & 1.50 & 5.65 & & 3.91 & 2.83 & 2.28 & 1.49 & 1.16 & 3.90 & 1.75 \\
\hline 2006 & 1.10 & 5.19 & & 4.32 & 2.90 & 2.14 & 1.28 & 1.22 & 3.75 & 1.64 \\
\hline \multicolumn{11}{|l|}{ Singapore } \\
\hline 1980-1989 & N/a & 23.86 & 3.55 & & 8.69 & 4.40 & 1.26 & 1.31 & 1.50 & 1.33 \\
\hline 1990-1999 & $\mathrm{N} / \mathrm{a}$ & 13.87 & 3.25 & & 5.16 & 7.05 & 1.38 & 1.24 & 1.36 & 1.00 \\
\hline $2000-2004$ & 7.45 & 13.51 & 3.63 & & 4.52 & 5.65 & 1.73 & 0.84 & 1.39 & 1.31 \\
\hline 2005 & 12.52 & 12.56 & 3.60 & & 4.11 & 5.80 & 1.54 & 0.67 & 1.22 & 1.52 \\
\hline 2006 & 13.01 & 12.17 & 3.82 & & 4.28 & 5.71 & 1.37 & 0.68 & 1.24 & 1.63 \\
\hline \multicolumn{11}{|l|}{ Thailand } \\
\hline 1980-1989 & 2.32 & 6.15 & 1.29 & 5.53 & & 1.47 & 1.22 & 1.17 & 2.50 & 1.98 \\
\hline 1990-1999 & 2.29 & 2.71 & 1.64 & 5.26 & & 4.19 & 0.73 & 1.30 & 2.86 & 0.93 \\
\hline $2000-2004$ & 4.14 & 3.94 & 2.98 & 4.51 & & 5.34 & 0.88 & 1.10 & 3.01 & 1.32 \\
\hline 2005 & 4.66 & 4.97 & 3.65 & 4.13 & & 6.42 & 0.90 & 0.99 & 3.03 & 1.46 \\
\hline 2006 & 3.63 & 4.75 & 4.06 & 3.79 & & 6.74 & 0.88 & 1.00 & 2.87 & 1.51 \\
\hline \multicolumn{11}{|l|}{ Vietnam } \\
\hline 1980-1989 & 1.24 & 0.49 & 0.00 & 4.17 & 0.55 & & 0.90 & 0.00 & 1.47 & 0.00 \\
\hline
\end{tabular}




\begin{tabular}{c|c|c|c|c|c|c|c|c|c|c}
\hline $\begin{array}{c}\text { Exporter } \\
\text { (Period) }\end{array}$ & $\begin{array}{c}\text { Indon- } \\
\text { esia }\end{array}$ & $\begin{array}{c}\text { Malay- } \\
\text { sia }\end{array}$ & $\begin{array}{c}\text { Philip- } \\
\text { pines }\end{array}$ & $\begin{array}{c}\text { Singa- } \\
\text { pore }\end{array}$ & $\begin{array}{c}\text { Thaila- } \\
\text { nd }\end{array}$ & $\begin{array}{c}\text { Vietna- } \\
\boldsymbol{m}\end{array}$ & Korea & U.S. & Japan & China \\
\hline $1990-1999$ & 2.81 & 1.31 & 3.81 & 5.81 & 2.36 & & 1.80 & 0.19 & 3.72 & 1.90 \\
\hline $2000-2004$ & 3.03 & 2.00 & 3.50 & 3.35 & 2.08 & & 1.14 & 0.84 & 3.12 & 2.26 \\
\hline 2005 & 1.88 & 3.00 & 5.04 & 3.52 & 2.66 & & 0.90 & 1.17 & 2.98 & 1.76 \\
\hline 2006 & 3.42 & 2.93 & 4.02 & 2.68 & 2.40 & & 0.90 & 1.32 & 2.99 & 1.36 \\
\hline Korea & & & & & & & & & & \\
\hline $1980-1989$ & 1.89 & 1.35 & 1.72 & 1.37 & 1.47 & 0.07 & & 2.25 & 2.93 & 0.00 \\
\hline $1990-1999$ & 3.49 & 1.90 & 2.55 & 1.94 & 1.60 & 5.42 & & 1.27 & 2.26 & 2.58 \\
\hline $2000-2004$ & 2.89 & 1.61 & 2.63 & 1.49 & 1.39 & 4.34 & & 1.13 & 2.02 & 3.52 \\
\hline 2005 & 2.31 & 1.54 & 2.23 & 1.55 & 1.19 & 3.64 & & 0.94 & 1.88 & 3.85 \\
\hline 2006 & 2.13 & 1.50 & 2.47 & 1.72 & 1.34 & 3.43 & & 0.89 & 1.86 & 3.57 \\
\hline
\end{tabular}

Source: Authors' calculation based on the Direction of Trade Statistics CD-Rom, IMF, 2008.

Three more important points should be highlighted in the export patterns of the ASEAN countries during the past two decades. Firstly, intra-regional trade between ASEAN countries has increased over time, but has occurred only among the original members (ASEAN-6). For new member countries (CLMV), intra-regional trade with ASEAN has actually declined since the mid-1990s, when most of those countries became members of AFTA. Secondly, ASEAN's exports to Korea have increased moderately in the past two decades, but these exports were only from ASEAN-6 countries. Thirdly, the export patterns of CLMV countries differed from those of ASEAN-6 countries and Korea. CLMV's exports to the U.S. and the EU increased dramatically, whereas those to China increased only moderately.

To acquire a deeper understanding of the trade flows, we applied a number of indices such as trade intensity, intra-industry trade, revealed comparative advantage, and regional orientation. These indices allowed us to gain additional insights into changes in the magnitude and direction of bilateral trade between Korea and ASEAN.

The trade intensity index (TII)2) was used to determine whether a country exported more (as a percentage) to a given destination than the world did on average. As shown in Table 3, the bilateral trade between major ASEAN countries was highly intense beginning in the early 1980s (except for Vietnam and Indonesia). Not only did ASEAN countries trade intensively with one another, but their bilateral trade with Korea also produced indices whose values were greater than the unity, particularly for Malaysia (3.5) and Indonesia (2.07). However, in the 1990s, the bilateral trade between Korea and some ASEAN members such as Malaysia, the Philippines, and Thailand

2) $T I I_{i j}=\left(x_{i j} / X_{i t}\right) /\left(x_{w j} / X_{w t}\right)$, where $x_{i j}$ and $x_{w j}$ denote the exports of country $\mathrm{i}$ and the world to country $\mathrm{j}$, respectively, and $X_{i t}$ and $X_{w t}$ are the total exports of country $\mathrm{i}$ and the world, respectively. 
declined, whereas the trade intensity among ASEAN members increased substantially, particularly in the early 2000s. In addition, the ASEAN members' trade with China has become more intense during this same period.

Since the 1980s, Korea has considered its trade with ASEAN countries to be vital. This importance is reflected in Korea's TII with major ASEAN countries, which was already greater than the unity in the 1980s (except for Vietnam). These indices increased further in the 1990s, indicating that Korea's trade with ASEAN countries was far more intense than its trade with the rest of the world, particularly with respect to its trade with Vietnam (5.42), Indonesia (3.49), and the Philippines (2.55). However, Korea's TII with major ASEAN countries has decreased since the early 2000s, indicating that Korea's trade with ASEAN has become less intense, although these indices have remained greater than the unity. This can be partly explained by the fact that, as discussed earlier, trade intensity among ASEAN countries has increased in recent years and by the emergence of China as an important trading partner of both Korea and ASEAN.

We then employed the intra-industry trade (IIT) index ${ }^{3)}$ to measure changes in the structure of sectoral trade flows between Korea and the ASEAN countries. We calculated the intra-industry trade for 15 major commodities of Korea's exports. Moreover, following Brulhart (1994), we examined marginal IIT (MIIT)4) to ascertain the importance of changes in trade flows that result in increases in IIT. As shown in Table 4, the results for IIT and MIIT indicate that the degree of intra-industry trade between Korea and ASEAN in 1990 was far less intensive than it was in 2006. Only 4 of the 15 industries recorded a high IIT index (greater than 0.5) in 1990. However, in 2006, the number of industries with high IIT indices increased to 9. Proportionally, the petroleum and petroleum products (SITC 33) showed the largest increase in IIT; the IIT index increased fourteen-fold from 0.063 in 1990 to 0.918 in 2006. This increase in IIT reflects the importance of Korea's complementary links with ASEAN economies, which have been strengthening since the early 1990s.

With regard to MIIT, it is noteworthy to point out that industries' with high IIT values also tended to have high MIIT values, implying relatively low adjustment costs. The MIIT value of chemical elements and compounds (51) was the highest among the

3) $I I T_{i}=1-\left(\left|X_{i}-M_{i}\right|\right) /\left(X_{i}+M_{i}\right)$, where $X_{i}$ and $M_{i}$ are Korea's exports and imports of commodity i during a particular time period, respectively. This measure ranges between zero and one; the former value denotes completely inter-industry trade, whereas the latter implies completely intra-industry trade.

4) $B_{i}=1-\left(\left|\Delta X_{i}-\Delta M_{i}\right|\right) /\left(\left|\Delta X_{i}\right|+\left|\Delta M_{i}\right|\right)$, where $\Delta$ is the difference operator, $\Delta \mathrm{X}$ represents changes in exports, and $\Delta M$ represents changes in imports between two years under investigation. This index varies between zero and unity; zero indicates marginal trade in a particular industry to be completely of the inter-industry type, whereas unity shows marginal trade to be entirely of the intra-industry type. 
examined industries, reflecting the lowest adjustment cost. On the other hand, the MIIT of transport equipment (73) was the lowest. This indicates that the changes in the structure of trade flows in transport equipment between Korea and ASEAN countries from 1990 to 2006 were predominantly inter-industry changes, implying potentially high adjustment costs.

Table 4.

IIT and MIIT Between Korea and ASEAN by SITC-2 Digit Level

\begin{tabular}{|c|c|c|c|c|}
\hline \multirow{2}{*}{$\begin{array}{c}\text { SITC } \\
\text { Rev. } 1\end{array}$} & \multirow{2}{*}{ Industry } & \multicolumn{2}{|c|}{ Intra-Industry Trade } & \multirow{2}{*}{ MIIT } \\
\hline & & 1990 & 2006 & \\
\hline 26 & Textile fibers, not manufactured & 0.498 & 0.269 & 0.222 \\
\hline 33 & Petroleum and petroleum products & 0.063 & 0.918 & 0.854 \\
\hline 51 & Chemical elements and compounds & 0.671 & 0.912 & 0.942 \\
\hline 54 & Medicinal and pharmaceutical products & 0.408 & 0.649 & 0.672 \\
\hline 58 & Plastic materials, etc. & 0.132 & 0.328 & 0.350 \\
\hline 61 & Leather, leather manufactures & 0.182 & 0.092 & 0.102 \\
\hline 62 & Rubber manufactures, n.e.s. & 0.291 & 0.994 & 0.777 \\
\hline 66 & Non-metallic mineral manufactures & 0.995 & 0.659 & 0.575 \\
\hline 67 & Iron and steel & 0.141 & 0.147 & 0.149 \\
\hline 69 & Manufactures of metal, n.e.s. & 0.158 & 0.270 & 0.318 \\
\hline 71 & Machinery, other than electric & 0.533 & 0.625 & 0.649 \\
\hline 72 & Electrical machinery, apparatus and appliances & 0.463 & 0.882 & 0.925 \\
\hline 73 & Transport equipment & 0.200 & 0.073 & 0.054 \\
\hline 86 & Scientific \& control instruments, photographs & 0.926 & 0.652 & 0.612 \\
\hline 89 & Miscellaneous manufactured articles & 0.414 & 0.945 & 0.819 \\
\hline
\end{tabular}

Note: 1) MIIT measures changes in intra-industry trade between 1990 and 2006.

Source: Authors' calculation based on the COMTRADE database.

Following the procedure described in Yeats (1998), we compared the regional orientation index with the revealed comparative advantage index to measure the extent to which the regional trade orientation of ASEAN and Korea were consistent with their comparative advantages. The regional orientation index $(\mathrm{ROI})^{5)}$ was used to determine

5) $R O I_{k}=\left(x_{k i j} / X_{i j}\right) /\left(x_{k i w} / X_{i w}\right)$, where $x_{k i j}$ and $x_{k i w}$ represent country i's exports of product $\mathrm{k}$ to country $\mathrm{j}$ and to the world, respectively and $X_{i j}$ and $X_{i w}$ represent country i's exports to country $\mathrm{j}$ and to the world, respectively. This index value ranges between zero and infinity; unity indicates the same tendency to export a good to both members and non-members, and a value greater than unity implies a stronger tendency to export to members than to non-members. 
the importance of intra-regional exports relative to extra-regional exports. The revealed comparative advantage (RCA) index ${ }^{6}$ ) was used to determine whether Korean exports to ASEAN countries were the ones in which Korea enjoys a comparative advantage and vice versa.

Table 5 shows the results for the RCA index and the ROI for 19 industry groups for Korea and ASEAN.7) Of the 19 industry groups, Korea had a comparative advantage in 12 industry groups in 2006, whereas ASEAN enjoyed a comparative advantage in 10. It is worthy to note that, according to the RCA index, the comparative advantage of Korea's trade structure was different from that of ASEAN's. That is, Korea had a comparative advantage in manufacturing industry groups, whereas ASEAN had a comparative advantage in primary industry groups. For example, in 2006, Korea had the greatest comparative advantage in electrical machinery, apparatuses, and appliances (72), whereas ASEAN enjoyed the strongest comparative advantage in crude rubber, including synthetic and reclaimed (23). In terms of the ROI, the regional trade orientation of both Korea in the ASEAN market and ASEAN in the Korean market was weaker in 2006 than in 1990; this was particularly the case for ASEAN.

The results of a comparison between the RCA index and the ROI suggest that the regional orientation of the two partners was stronger in industry groups whose products had a comparative advantage. This implies that the bilateral exports of Korea and ASEAN were consistent with their comparative advantages. For example, among the 9 industry groups who registered a strong regional orientation for Korea's exports to ASEAN in 2006, all but animal and vegetable oils and fats (43) and wood and cork manufactures (63) enjoyed a comparative advantage (Table 5). In the case of ASEAN's exports to Korea, the results shown in Table 5 indicate that ASEAN enjoyed a comparative advantage in 4 of the 5 industry groups that exhibited a strong regional orientation; the exceptions were textile yarn, fabrics, made-up articles, and related products $(65)$.

In conclusion, the trade patterns between Korea and ASEAN have changed substantially in the past two decades. Several important changes are as follows: First, intra-industry trade tended to be much higher for manufactured goods than for non-manufactured goods. The level of intra-industry trade between Korea and ASEAN

6) $R C A_{i j}=\left(x_{i j} / X\right) /\left(x_{w j} / X_{w t}\right)$, where $\mathrm{x}_{\mathrm{ij}}$ and $\mathrm{x}_{\mathrm{wj}}$ denote the exports of product $\mathrm{j}$ by country $\mathrm{I}$ and by the world ,respectively, and $X_{i}$ and $X_{w t}$ refer to the total exports of country I and the world, respectively.

7) For both ASEAN and Korea, we selected 10 industry groups that recorded the highest RCA values in 2006. There was an industry group that satisfied this criterion for both ASEAN and Korea, and thus, a total of 19 industry groups were selected (see Table 5). 
increased over time, indicating the importance of Korea's trade links with ASEAN economies. Second, Korea enjoyed a comparative advantage in manufacturing industry groups, whereas ASEAN countries enjoyed the same in primary industry groups. Therefore, the results suggest that the structure of bilateral trade is consistent with the comparative advantage of the respective countries. Finally, despite the considerable expansion of trade between Korea and the ASEAN countries in recent years, the degree of bilateral trade between them has decreased in intensity, and the extent of the regional trade orientation of both Korea and ASEAN to their respective markets has weakened. This can be explained in part by an increase in trade intensity among the ASEAN countries and by the emerging role of China in the Korean and ASEAN markets. 


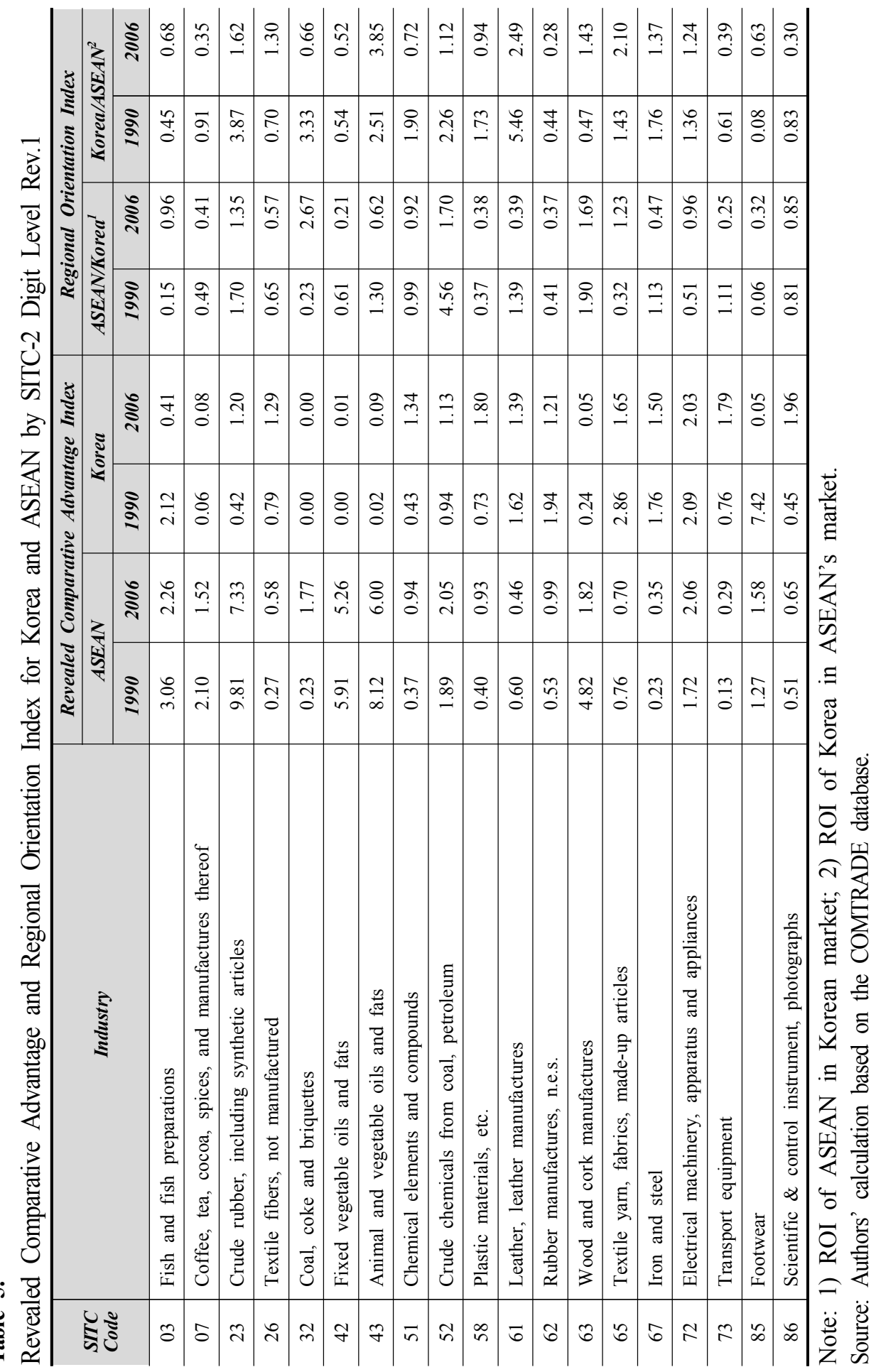




\section{METHODOLOGY}

\section{a. Model Specification}

To examine the effects of the AFTA on Korea's sectoral exports to ASEAN countries, we specified our augmented gravity model as follows 8$)$ :

$$
\begin{aligned}
& L n E X_{h k j t}=\beta_{0}+\beta_{l} \ln P C G D P_{j t}+\beta_{2} \ln P O P_{j t}+\beta_{3} \ln D I S T_{k j}+\beta_{4} \ln A R E A_{j}+ \\
& \beta_{5} \ln X R_{j i t} \beta_{6} \ln P C G D P P_{-} D I F_{k j t}+\beta_{7} W T O_{j t}+\beta_{8} A F T A_{j t}+\beta_{9} \ln E X_{h k j t-1}+f \text { Year }_{t}+e_{k j}
\end{aligned}
$$

where

* $\mathrm{EX}_{\mathrm{hkjt}}$ and $\mathrm{EX}_{\mathrm{hkjt}-1}$ are export volumes of Korea's sector $h$ to country $j$ (ASEAN) at times $\mathrm{t}$ and $\mathrm{t}-1$, respectively.

* PCGDP $\mathrm{jt}_{\mathrm{jt}}$ is the per capita GDP of importing country $j$ at time t.

* $\mathrm{POP}_{\mathrm{jt}}$ is the population of importing country $j$ at time $\mathrm{t}$.

* DIST $_{\mathrm{kj}}$ is the geographical distance (measured as the crow flies) between the capital of Korea (country $k$ ) and that of country $j$.

* $\mathrm{AREA}_{\mathrm{j}}$ is the total area (measured in nautical miles) of country $j$.

* $\mathrm{XR}_{\mathrm{jit}}$ is the real exchange rate of country $j$ 's currency against the Korean won in year $t$.

* PCGDP_DIF ${ }_{\mathrm{kjt}}$ is the difference in per capita GDP between Korea and country $j$ at time $\mathrm{t}$ (in absolute value).

* $\mathrm{WTO}_{\mathrm{jt}}$ is a dummy variable that equals 1 if country $j$ is a member of the WTO and 0 otherwise at time t.

* AFTA $_{\mathrm{jt}}$ is a dummy variable that equals 1 if country $j$ belongs to the AFTA and 0 otherwise at time $\mathrm{t}$.

* Year ${ }_{t}$ is a set of binary variables that represent unity in the specific year t.

* $\mathrm{e}_{\mathrm{kj}}$ represents the error terms.

To date, most of the previous empirical studies have used aggregate bilateral trade

8) For the background and recent application of the gravity model, see Braga, Safadi, and Yeats (1994), Mátyás (1997), Greenaway and Milner (2002), Anderson and van Wincoop (2003), and Baierand Bergstrand (2007).To capture the Linder effect, we employed absolute differences in the per capita GDP (PCGDP DIF) of any two countries. A negative sign of the per capita GDP difference variable would support the hypothesis, whereas a positive sign would support the Hechscher-Ohlin hypothesis. In addition, the role of the exchange rate in determining trade flows is well known (Bergstrand, 1989; Micco, Stein \& Ordoñez, 2003). The population and per capita GDP replace GDP in the equation. 
as the dependent variable (Rose, 2004). As mentioned by Dhar and Panagariya (1999) and others, total trade should not be used as a dependent variable because this approach imposes the equality of coefficients on imports and exports, which may not be tenable. Previous empirical studies have demonstrated that the gravity equation can be successfully applied to commodity trade (Bergstrand, 1989; Martínez-Zarzoso \& Nowak-Lehmann, 2004; Jayasinghe \& Sarker 2007). When countries negotiate an FTA, because of the domestic resistance of influential interest groups, countries frequently exclude sensitive products from tariff reduction schemes under the FTA. This is particularly the case with the AFTA; a number of sensitive products were excluded from the CEPT scheme. Thus, the use of sectoral panel data has been recommended for evaluating the impact of an FTA on trade flows by using the gravity equation.

Following Harris and Mátyás (1998), Badinger and Breuss (2004), and De Benedictis and Vicarelli (2005), we estimated the gravity equation by using a dynamic estimator (using a lagged dependent variable as one of the regressors), which allowed us to evaluate the short- and long-run dynamics more precisely. Repeated interactions between business partners, as well as sunk costs associated with distribution and service networks, warrant a dynamic relationship within the model (De Nardis and Vacarelli, 2005). Therefore, it is appropriate to hypothesize that past exports can exert a substantial impact on current exports.

\section{b. Data and the Estimation Method}

The presence of a lagged dependent variable as one of the regressors can lead to biased and inconsistent estimated coefficients for OLS and fixed-effects estimators (Nickell, 1981; Sevestre and Trognon, 1985; Baltagi, 2001; Harris and Mátyás, 2004). As Nickell (1981) demonstrated, fixed-effects estimators yield a downward bias, whereas OLS estimators generate an upward bias (Hsiao, 1986). Arellano and Bond (1991) developed the first-differenced GMM (DIF-GMM) to correct these problems. However, Blundell and Bond (1998) and Bond et al. (2001) demonstrated that the DIF-GMM may be subject to a large downward finite-sample bias, particularly in cases in which the number of available time periods is small. It has been shown that the SYS-GMM estimator brings about a noticeable improvement in the small-sample bias and precision relative to the DIF-GMM estimator, particularly when the dependent variable is highly persistent (De Mello-Sampayo, 2009). Because the bilateral trade flows between Korea and ASEAN were expected to change slowly as a result of the persistence of trade relationships as well as sunk costs, the SYS-GMM estimator was considered to be more appropriate for our model than the DIF-GMM estimator.

This study used export data at the two-digit level of the SITC (Rev.1); this data 
spanned from 1980 to 20069). The data on exports for Korea and ASEAN-10 at the two-digit level of the SITC were drawn from the UN COMTRADE database. In terms of the explanatory variables, the data on per capita GDP (in 2000 U.S. dollars), the population, and the area (in square $\mathrm{km}$ ) were drawn from the World Bank's World Development Indicators CD-ROM. The data on the geographical distance between the capital of Korea and those of the ASEAN countries were drawn from the Centre d'Etudes Prospectives et d'Informations Internationales (CEPII) website. The data regarding the real exchange rates came from the Economic Research Service branch of the U.S. Department of Agriculture. Table 6 provides a summary of the statistics for these variables.

Table 6.

Summary Statistics

\begin{tabular}{c|c|c|c|c|c}
\hline Variable & Observation & Mean & $\begin{array}{c}\text { Standard } \\
\text { Deviation }\end{array}$ & Minimum & Maximum \\
\hline Ln Exports & 9063 & 13.77 & 3.18 & 1.10 & 22.29 \\
\hline Ln POP & 9063 & 17.08 & 1.67 & 12.17 & 19.22 \\
\hline Ln PCGDP & 9063 & 7.31 & 1.48 & 4.75 & 10.31 \\
\hline Ln AREA & 9063 & 11.93 & 2.50 & 6.51 & 14.41 \\
\hline Ln Exchange rate & 9063 & -2.77 & 3.36 & -6.91 & 2.77 \\
\hline Ln DIST & 9063 & 8.26 & 0.24 & 7.87 & 8.57 \\
\hline Ln DIF-PCGDP & 9063 & 8.88 & 0.51 & 7.23 & 10.19 \\
\hline WTO & 9063 & 0.83 & 0.38 & 0 & 1 \\
\hline AFTA & 9063 & 0.56 & 0.50 & 0 & 1 \\
\hline
\end{tabular}

Source: Calculation from the data set.

\section{DISCUSSION of the EMPIRICAL RESULTS}

The estimated results are shown in Table 7. When compared to the lagged dependent variable's coefficient from the SYS-GMM estimator (0.69), the OLS estimator's coefficient had an upward bias of 0.90, and the fixed-effects estimator's coefficient had a downward bias of 0.53 .

9) The Korea-ASEAN (except Thailand) FTA for the goods sector took effect in 2007. FTAs related to the service and investment sectors became effective in 2009. Thus, we observe the sample period (1980 to 2006) during which only ASEAN members (excluding Korea) enjoyed preferential treatment from each other. 
Table 7.

Regression Results for the Aggregate Data

\begin{tabular}{|c|c|c|c|c|c|c|}
\hline \multirow{2}{*}{ Independent Variables } & \multicolumn{2}{|c|}{ OLS } & \multicolumn{2}{|c|}{ Fixed Effects } & \multicolumn{2}{|c|}{$S Y S-G M M$} \\
\hline & Coef. & t-statistic & Coef. & t-statistic & Coef. & t-statistic \\
\hline Lagged Exports & $0.90^{\mathrm{a}}$ & 189.61 & $0.53^{\mathrm{a}}$ & 57.03 & $0.69^{\mathrm{a}}$ & 3.31 \\
\hline PCGDP $_{j}$ & $0.11^{\mathrm{a}}$ & 5.04 & $0.15^{\mathrm{c}}$ & 1.71 & $0.59^{\mathrm{a}}$ & 4.17 \\
\hline $\mathrm{POP}_{\mathrm{j}}$ & $0.14^{\mathrm{a}}$ & 7.09 & $0.67^{\mathrm{a}}$ & 3.68 & $1.05^{\mathrm{a}}$ & 8.07 \\
\hline $\mathrm{AREA}_{\mathrm{j}}$ & -0.01 & -1.11 & -0.82 & -0.52 & $-0.28^{\mathrm{a}}$ & -2.83 \\
\hline Exchange rate $_{\mathrm{ij}}$ & 0.00 & -0.19 & -0.03 & -1.16 & -0.04 & -0.76 \\
\hline $\operatorname{DIST}_{\mathrm{ij}}$ & -0.09 & -1.32 & $\mathrm{~N} / \mathrm{a}$ & $\mathrm{N} / \mathrm{a}$ & -0.07 & -0.12 \\
\hline DIF-PCGDP $_{\mathrm{ij}}$ & $0.11^{\mathrm{b}}$ & 2.51 & $0.69^{\mathrm{a}}$ & 11.75 & -0.29 & -1.28 \\
\hline WTO & -0.09 & -1.58 & $0.57^{\mathrm{a}}$ & 6.86 & $-0.59^{c}$ & -1.79 \\
\hline AFTA & $-0.12^{\mathrm{a}}$ & -3.12 & -0.001 & -0.02 & -0.09 & -0.81 \\
\hline Constant & $-1.52^{\mathrm{c}}$ & -1.91 & -2.76 & -0.15 & -3.27 & -0.66 \\
\hline No. of obs. & \multicolumn{2}{|c|}{8059} & \multicolumn{2}{|c|}{8059} & \multicolumn{2}{|c|}{8059} \\
\hline R-Square & \multicolumn{2}{|c|}{0.85} & \multicolumn{2}{|c|}{0.48} & & \\
\hline $\mathrm{AB}$ (2) test & & & & & \multicolumn{2}{|c|}{0.13} \\
\hline Sargan test (P-value) & & & & & \multicolumn{2}{|c|}{0.89} \\
\hline
\end{tabular}

Note: 1. The dependent variable is Ln (Exports).

2. All variables except dummies (WTO and AFTA) are expressed in natural logarithms.

3. Subscripts ${ }^{\mathrm{a}}, \mathrm{b}$, and ${ }^{\mathrm{c}}$ indicate statistical significance at the $1 \%, 5 \%$, and $10 \%$ levels, respectively.

4. Coefficients of time dummies are not reported.

The results obtained by using the SYS-GMM estimator indicate that the gravity model provided a good fit with the aggregate data, explaining a large portion of the variation in bilateral trade flows. The key estimated coefficients were statistically significant at a high level of significance. When compared with the OLS and fixed effects estimators, the SYS-GMM estimator resulted in an improvement in the explanatory power of the per capita GDP and population variables. In addition, the lagged dependent variable (lagged exports) was found to be an important explanatory variable for all model specifications. This suggests a need for considering the role of a lagged dependent variable in the gravity model. In the SYS-GMM, the per capita GDP variable had a significant positive effect on exports. The positive sign of per capita GDP suggests that an increase in individual income can increase purchasing power, which in turn can stimulate import demand. Specifically, all other things being equal, every $10 \%$ increase in the per capita GDP of the ASEAN countries produced a $6.9 \%$ increase in their demand for Korean exports. The estimated coefficient of the 
importing country's population was positive and highly statistically significant, suggesting that country size is related directly to the amount of trade that a country conducts. Larger countries also have a greater capacity to absorb imports than smaller countries. In fact, it is worth noting that the population coefficient was found to be the most important variable influencing the direction of Korea's exports to ASEAN countries. The dummy variable for the ASEAN countries being WTO members showed a statistically significant negative effect on Korean exports. This suggests that ASEAN countries tend to divert their imports away from Korea to more efficient countries when they become WTO members. This result supports Rose's (2004) study, in which he determined the negative impact of the WTO dummy on bilateral trade flows.

As noted earlier, our primary interest is in the impact of the AFTA on Korean exports to ASEAN countries. The regression results of the SYS-GMM estimator demonstrate that the formation of the AFTA had a significant negative relationship for Korean exports to ASEAN countries. This implies that the formation of the AFTA did not have a substantial effect on Korean exports to ASEAN countries. This result is also consistent with the findings of Lee and Park (2005) and Calvo-Pardo, Freund, and Ornelas (2009) on the impact of the AFTA on non-member countries. The present study, using aggregate data, found no evidence that the AFTA harms non-members by diverting AFTA members' imports from non-member countries to AFTA's members. This implies that the AFTA can be a "building block" to free trade. Moreover, Lee, Koo, and Park (2008) found that trade creation was demonstrated by Korea's exports to the AFTA bloc. However, we need to note that the tariff reduction and elimination process under the AFTA has been implemented differently across individual sectors. In addition, sectoral heterogeneous effects can be cancelled out at the aggregate level, resulting in aggregation bias in trade diversion effects.

For the abovementioned reasons, we estimated the gravity equation for 15 major sectors based on their export share in Korea's total exports. Table 8 presents the estimated coefficients. Overall, the gravity model worked well and yielded consistent outcomes across sectors. The estimated coefficients for the AFTA varied across sectors. The estimated coefficients that were negative and statistically significant included 5 sectors: medicinal and pharmaceutical products (54); plastic materials (58); rubber manufactures (62); non-metallic mineral manufactures (66); and scientific/control instruments and photographs (86). This implies that the formation of the AFTA has diverted Korea's exports to ASEAN members for these specific sectors. In real terms, Korea's exports of these products to ASEAN countries declined or increased only minimally in value between 1995 and 2005.10) Moreover, the intra-regional trade

10) Korea exported $42 \%$ less non-metallic mineral manufactures and $10 \%$ less rubber manufactures to the ASEAN countries between 1995 and 2005. In plastic materials (58) and scientific/control 
among the ASEAN countries increased considerably for most of these products. ${ }^{11)}$

On the other hand, the estimated coefficient for petroleum (33) was positive and statistically significant. This positive coefficient can be explained by the special characteristics found in the sector's products, which are important inputs for the industrialization of the ASEAN countries. In fact, Korea and ASEAN countries have demonstrated a complementary relationship in terms of producing and refining petroleum products; most ASEAN countries are endowed with abundant crude oil, whereas Korea has advanced oil refinery technology. In monetary terms, Korea's exports of petroleum and petroleum products to the ASEAN countries increased dramatically from \$53.8 million in 1990 to \$3.5 billion in 2005 .

In terms of the remaining 9 sectors, the coefficients for the AFTA were either positive or negative, but they were statistically insignificant. Overall, the estimated results for the 15 sectors indicate that trade diversion effects dominated trade creation effects in Korea-ASEAN trade flows under the AFTA. The results of the comparison between the aggregate and sectoral approaches confirm that the latter provides more robust and clear-cut results than the former.

One of the most salient points in Table 8 is the marked consistency in the behavior of the estimated coefficients for the lagged exports across all sectors regardless of the sector's characteristics. The coefficients were positive and highly significant (mostly at the $1 \%$ level) for all of the sectors. This result reflects the fact that there are repeat interactions between exporters and importers as well as sunk costs related to the distribution and service networks. Therefore, the exclusion of a lagged dependent variable in the gravity equation may lead to serious bias in the estimated results.

instruments and photographs (86), Korea's exports to the ASEAN countries increased by $80 \%$ and $25 \%$, respectively, during the same period, whereas those to China increased by $259 \%$ and $10,069 \%$, respectively (UNSD, 2008). Both Korea and the ASEAN countries have enjoyed sharp increases in trade with China since the early 1990s. Thus, the China factor may be responsible for altering trade between Korea and the ASEAN countries.

11) For example, the share of intra-regional trade in total trade in plastic materials (58) increased from $25 \%$ in 1992 to $32 \%$ in 2006 ; rubber manufactures (62), from $17 \%$ to $28 \%$; non-metallic mineral manufactures (66), from $18 \%$ to $22 \%$; and scientific/control instruments and photographs (86), from $15 \%$ to $24 \%$. The share in medicinal and pharmaceutical products (54) declined slightly because the ASEAN countries diverted their imports from Korea to other non-member sources such as China. 


\begin{tabular}{|c|c|c|c|c|c|c|c|c|c|c|}
\hline $\begin{array}{l}\dot{\theta} \\
\dot{z} \\
\dot{z}\end{array}$ & 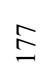 & $\underset{\infty}{\infty}$ & $\stackrel{\infty}{\infty}$ & $\nsubseteq$ & $\stackrel{\sim}{\sim}$ & $\stackrel{I}{I}$ & ণั & $\stackrel{ \pm}{2}$ & & $\stackrel{n}{\sim}$ \\
\hline 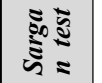 & $\begin{array}{l}\mathscr{0} \\
\stackrel{0}{0}\end{array}$ & ஜ़. & ๙ุ & $\stackrel{n}{0}$ & $\stackrel{\infty}{\stackrel{\infty}{0}}$ & F. & $\stackrel{\infty}{0}$ & $\stackrel{\infty}{n}^{\infty}$ & â. & $\frac{n}{0}$ \\
\hline ₹ૈลิ & $\stackrel{n}{o}$ & ֻั & $\bar{m}$ & సี & $\mid \begin{array}{l}0 \\
\infty \\
0\end{array}$ & 年 & $\stackrel{3}{0}$ & $\frac{5}{8}$ & $\frac{0}{0}$ & ?ี \\
\hline
\end{tabular}

₹

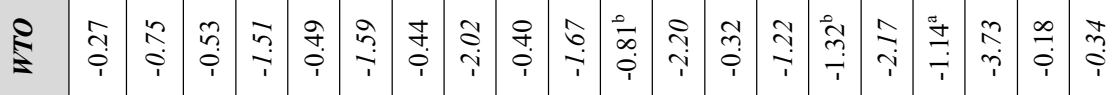

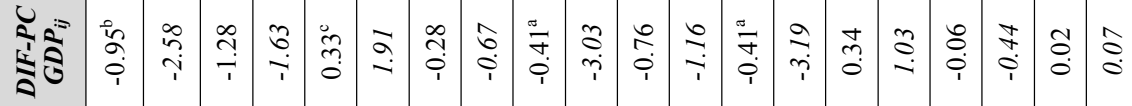

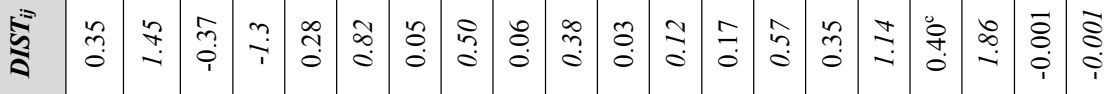

总

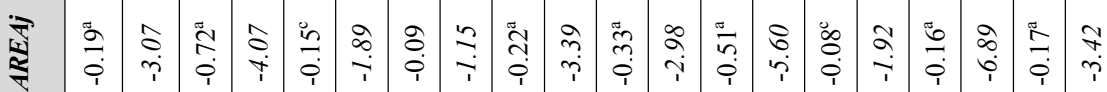

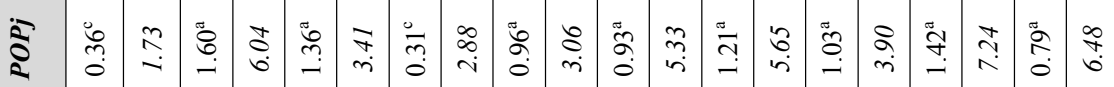

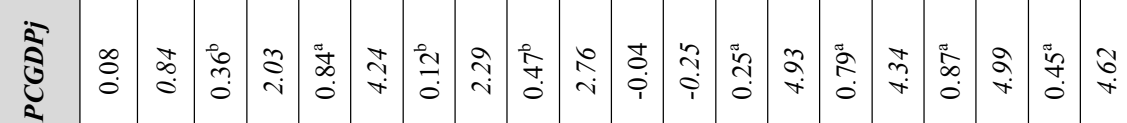

经

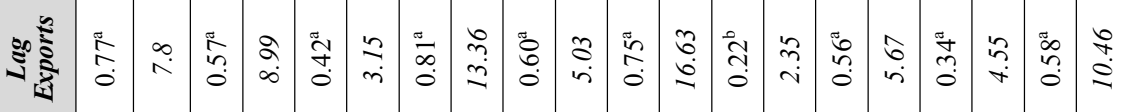

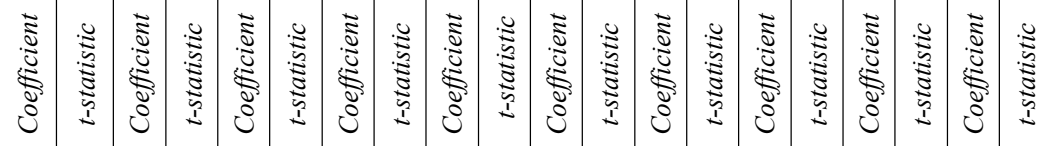


The estimated coefficients for importers' per capita GDP were positive and statistically significant for 13 of the 15 sectors at the SITC 2-digit level between 1980 and 2006. This suggests that these products tend to be income elastic. In fact, the demand for electrical machinery (72), transport equipment (73), medicinal and pharmaceutical products (54), and scientific and control instruments (86) has increased dramatically in recent years. The estimated coefficients for the population of ASEAN countries were all positive and statistically significant across all of the sectors. This demonstrates that demand by more populous countries can better absorb imports than that of less populous ones. In addition, the estimated coefficients for the area of trading partners were negative and largely statistically insignificant as expected.

The estimated coefficients for the real exchange rate of currencies of the ASEAN countries against the Korean won were negative and statistically significant for chemical elements and compounds (51), iron and steel (67), electrical machinery, apparatus and appliances (72), and scientific and control instruments (86), indicating that the depreciation of the ASEAN currencies can discourage imports from Korea. In reality, these sectors are all quite sensitive to changes in prices. For the other 10 sectors, the estimated coefficients for the real exchange rate were negative but statistically insignificant.

The estimated coefficients for the difference in per capita GDP support the Linder hypothesis for 6 sectors: textile fibers (26); plastic materials (58); rubber manufactures (62); machinery (71); transport equipment (73); and scientific/control instruments and photographs (86). These negative effects in the differences in per capita GDPI indicate that countries with similar per capita income levels tend to have similar demand patterns and produce similar but differentiated products, making them more likely to trade with each other. On the other hand, the estimated coefficient for chemical elements and compounds (51) were both positive and significant. The positive sign of this coefficient indicates that the Hechscher-Ohlin effect dominated the Linder effect.

\section{CONCLUSION}

The empirical results indicate that the effects of the AFTA on trade flows between Korea and the ASEAN countries differed widely across different sectors. For 5 of the 15 selected sectors, the AFTA had a negative effect on Korean exports to the ASEAN countries, whereas for the remaining 9, the effect was unclear. Overall, Korea's exports were diverted to the ASEAN members between 1980 and 2006 as a result of the AFTA formation. To provide an in-depth understanding of this diversion, 
we also examined the unique characteristics found in the trade patterns between Korea and the ASEAN countries. Our findings report several important structural changes. First, the level of intra-industry trade between Korea and the ASEAN countries increased over time, demonstrating the importance of Korea's complementary links with ASEAN economies. Second, Korea enjoyed a comparative advantage in the manufacturing industry groups, whereas the ASEAN countries evidenced the same in the primary industry groups. This suggests that the structure of bilateral trade between Korea and ASEAN is consistent with the comparative advantage. Finally, despite the dramatic expansion of trade between Korea and the ASEAN countries in recent years, the degree of bilateral trade between them became less intense, and the extent of the regional trade orientation of both Korea and ASEAN to their respective markets weakened. This can be explained in part by an increase in the trade intensity within the ASEAN countries, trade diversion from Korea to the ASEAN members, and the emerging role of China in the Korean and ASEAN markets. 


\section{REFERENCES}

Arellano, M. and S. Bond (1991), 'Some Tests of Specification for Panel Data: Monte Carlo Evidence and an Application to Employment Equations', The Review of Economic Studies, 58, 2, 277-97.

Anderson, J. E. and E. van Wincoop (2003), 'Gravity with Gravitas: A Solution to the Border Puzzle', American Economic Review, 93, 1, 170-92.

Baier, S. L. and J. H. Bergstrand (2007), 'Do Free Trade Agreements Actually Increase Members' International Trade?', Journal of International Economics, 71, 1, 72-95.

Braga, P., R. Sadafi and A. Yeats (1994) 'Regional Integration in the Americas: Déjà Vu All Over Again?', The World Economy, 17, 4, 577-601.

Bond, S. R., J. Temple and A. Hoeffler (2001), 'GMM Estimation of Empirical Growth Models', CEPR Discussion Papers 3048, London: Centre for Economic Policy Research.

Baltagi, B. H. (2001), Econometric Analysis of Panel Data (New York: Chichester).

Badinger, H. and F. Breuss (2004), 'What has Determined the Rapid Post-war Growth of Intra-EU Trade?', Review of World Economics, 140, 1, 31-51.

Bergstrand, J. H. (1989), 'The Generalized Gravity Equation, Monopolistic Competition, and the Factor-Proportions Theory in International Trade', The Review of Economics and Statistics, 71, 1, 143-53.

Blundell, R. and S. Bond (1998), 'Initial Conditions and Moment Restrictions in Dynamic Panel Data Models', Journal of Econometrics, 87, 1, 115-43.

Brülhart, M. (1994), 'Marginal Intra-Industry Trade: Measurement and Relevance for the Pattern of Industrial Adjustment', Weltwirtschaftliches Archiv, 130, 600-13.

Calvo-Pardo, H., C. Freund and E. Ornelas (2009), 'The ASEAN Free Trade Agreement Impact on Trade Flows and External Trade Barriers', Policy Research Working Paper No. 2960, Washington D.C.: The World Bank.

De Benedictis, L. and C. Vicarelli (2005), 'Trade Potentials in Gravity Panel Data Models', Topics in Economic Analysis and Policy, 5, 1, Article 20.

De Mello-Sampayo F. (2009), 'Competing-Destinations Gravity Model: An Application to the Geographic Distribution of FDI', Applied Economics, 41, 2237-53.

Dhar, S. and A. Panagariya (1999), 'Is East Asia Less Open Than North America and the EEC? No', in Piggott, J. and A. Woodland (eds.), International Trade Policy and the Pacific Rim (London: Macmillan).

Greenaway, D. and C. Milner (2002), 'Regionalism and Gravity', Scottish Journal of Political Economy, 49, 5, 574-85. 
Harris, M. N. and L. Mátyás (1998), 'The Econometrics of Gravity Models', Melbourne Institute Working Paper 5/98, Melbourne: Institute of Applied Economic and Social Research.

Hsiao, C. (1986), Analysis of Panel Data (Cambridge: Cambridge University Press).

International Monetary Fund (IMF) (2008), Direction of Trade Statistics CD-ROM, Washington D.C.: IMF.

Jayasinghe, S. and R. Sarker (2007), 'Effects of Regional Trade Agreements on Trade in Agrifood Products: Evidence from Gravity Modeling Using Disaggregated Data', Review of Agricultural Economics, 30, 1, 61-81.

Korea International Trade Association (KITA) (2007) 'Trade Statistics', Website: www.kita.org.

Lee, J. W. and I. W. Park (2005), 'Free Trade Areas in East Asia: Discriminatory or Non-discriminatory?', The World Economy, 28, 1, 21-48.

Lee, H. H, C. M. Koo and E. J. Park (2008), 'Are Exports of China, Japan and Korea Diverted in the Major Regional Trading Blocs?', The World Economy, 31, 7, 841-60.

Martínez-Zárzoso, I. and F. D. Nowak-Lehmann (2004), 'Economic and Geographical Distance: Explaining Mercosur Sectoral Exports to the EU', Open Economics Review, 15, 3, 291-314.

Mátyás L. (1997), 'Proper econometric specification of the gravity model', The World Economy, 20, 2, 363-8.

Micco, A., E. Stein and G. Ordoñez (2003), 'The Currency Union Effect on Trade: Early Evidence from EMU', Economic Policy, 18, 37, 315-56.

Nickell, S. (1981), 'Biases in Models with Fixed Effects', Econometrica, 49, 1417-426.

Rose, A. K. (2004), 'Do We Really Know that the WTO Increases Trade?', American Economic Review, 94, 1, 98-114.

Sevestre, P. and A. Trognon (1985), 'A Note on Autoregressive Error Component Models', Journal of Econometrics, 28, 231-45.

United Nations Statistics Division (2008), 'United Nations Commodity Trade Statistics Database (COMTRADE)', http://comtrade.un.org/db/default.aspx (accessed December 22, 2008).

World Bank (2008), 'World Development Indicators, CD-ROM', Washington D.C.: World Bank.

Yeats, A. J. (1998), 'Does Mercosur's Trade Performance Raise Concerns about the Effects of Regional Trading Arrangements?', World Bank Economic Review, 12, 1, 1-28. 